\title{
Development of Settlement Network of Yakutia in the XVIIth Century
}

\author{
E. N. Fedorova ${ }^{1}$ \\ ${ }^{1}$ Scientific-Research Institute of Regional Economy of the North, Yakutsk, Russia \\ Correspondence: E. N. Fedorova, Scientific-Research Institute of Regional Economy of the North, Yakutsk, \\ 677891, Russia. E-mail: ire2000@mail.ru
}

\author{
Received: April 1, 2014 Accepted: April 24, 2014 Online Published: May 16, 2014 \\ doi:10.5539/jgg.v6n2p155 URL: http://dx.doi.org/10.5539/jgg.v6n2p155
}

The article is prepared within the state task No. 3031 of research work "Economical demographic factors of balance of a labor market in transformed conditions of social and economic development of the Northeast of Russia" No. of the state registration 01201460077

\begin{abstract}
At all times Yakutia was particularly concerned with the issues of territorial structure and management due to the enormity of its territory, ample natural resources and its geographical and geopolitical location. Taking into account the changes in the territorial organization of the region in the XVIIth century allows us to trace the growth dynamics of its settlement network, the relationships between individual settlements and their totality, as well as to identify the differences between the existing settlement network and the problems related to the future development of the region.

The article discusses the changes in the territorial and organizational structure of the region and its internal parts within the context of general changes in the administrative division of the Russian state as a whole, and Siberia, in particular. Literary publications, historical documents containing the information about the basic changes in boundaries and structure, cartographic and descriptive materials served as the sources for studying this issue.

The use of the above mentioned sources allows us to determine that the territorial and organizational structure of the region at an early stage (before the service class people came there) was a location of tribal groupings and corresponded to places of locations of clans and tribes. Only with the introduction of the yasak tax the territory of inhabitance was divided into volosts (small rural districts). At first, that division was only a fixation of social structure of the Yakuts pursuant to the words of Yakut kniaztsy (elders of Siberian clans). First groups of service class people had neither time nor favorable conditions for exercising any administrative division. Initially, they were dealing with kniaztsy who occupied certain regions called volosts or uluses. Those were the first administrative units of territory management of the region in the XVIIth century.
\end{abstract}

Keywords: territorial and organizational structure, settlements, townships, administrative division, territory, ranks counties

\section{Problem Statement}

At all times Yakutia was particularly concerned with the issues of territorial structure and management due to the enormity of its territory, ample natural resources and its geographical and geopolitical location. Taking into account the changes in the territorial organization of the region in the XVIIth century allows us to trace the growth dynamics of its settlement network, the relationships between individual settlements and their totality, as well as to identify the differences between the existing settlement network and the problems related to the future development of the region.

\section{Subject and Resources of Study}

The article discusses changes in the territorial and organizational structure of the region and its internal parts within the context of general changes in the administrative division of the Russian state as a whole, and Siberia, in particular. Literary publications, historical documents containing the information about basic changes in boundaries and structure, cartographic and descriptive materials served as the sources for study of this issue. 


\section{Results of the Study}

The historical sources note that the annexation of Siberian territory to Russia began at the end of the XVIth century concurrently with migration to the Urals which started after Ermak's Cossack squad had defeated the last descendant of Genghis Khan - Kuchum- on the Irtysh River. The development of the territories began with the forest zone of the Western Siberia, then the East Siberia, and starting from the XVIIIth century-Southern Siberia. The main settler were peasants, hunters and craftsmen. As interpreted in historical sources, in the XVIth century Siberia was not yet regarded as a country completely annexed to Russia, that's why it fell into a category of so-called "foreign" countries regulated by the Bureau of Ambassadors.

After the Siberian territory was annexed to Russian, the authorities were not satisfied with the old order of relationship with the annexed regions. The documents on the Siberian history evidence that since 1956, when several administrative centers (Tyumen, Tobolsk, Pelym, Berezov, Surgut, Tura) already existed, uyezds (secondary level of administrative division) began to form. The uyezds regularly replenished the treasury with furs being collected as yasak from the local population. In the same year B. Godunov took the lead of Siberia which he kept until 1599. After this year pursuant to Godunov's order, the management of Siberian territory was regulated by Kazan and Meschersky households. These government offices ran the former territory of the Kazan Khanate, Volga region and the Urals annexed to Russia. A special Siberian ministry was formed, it was a part of the government until 1637 and regulated territories beyond the Urals. As a rule, persons who were especially close to the tsar, were assigned as chiefs of the Siberian ministry. The ministry ran the administrative apparatus of all the formed uyezds of the region, was in charge of the military forces, external relations with neighbors, collection of yasak, trade taxes, money and grain taxes, economic matters related to the agricultural development of the region by Russian settlers - all it was under the jurisdiction of the ministry (Nikolai, 1987).

As the researchers note, the first half of the XVIIth century in the history of Siberia is characterized by the rapid easterning of industrialists and service class people. There were several reasons for this. Trade relations with the West resumed after 1613 caused a need for intensified exploitation of the Siberian fur resources. The impoverishment also forced Pomors to see knew livelihoods, tore them from their farms and made them proceed to the territories beyond the Urals in search of furs. But as sable, which was the main target, was largely exterminated in Western Siberia, they had to look for new places, and enterprising Pomor industrialists penetrated deeper into regions, inhabited by natives and were followed by the service class people and yasak collectors.

We find in the above-mentioned source "History of Siberia" that up to 1629 Tobolsk was the main administrative center which, to some extent, subordinated all other cities and forts. In 1629 management of Siberia was divided into two razryads (literary orders or units) or regions. Tomsk was made the second regional or provincial city subordinating such cities as Krasnoyarsk, Yeniseisk, Kuznetsk, Harym and Ket fort, which in their turn, subordinated forts and winter huts (Figure 1). Administratively, the territory of Siberia was divided into uyezds, which by the end of the century were 19 (Nikolai, 1987).

Meanwhile, it was necessary to solidify in the annexed lands and provide further penetration to the North and East up to the Arctic and Pacific Oceans, systematic use of fur wealth of these regions had to be started. Replenishment of the treasury with furs worth their weight in gold was one of the main factors motivating authorities of the Russian Empire to develop and bring new lands "to the tsar's hand". In the early XVIIth century this aspiration attracted many pioneers to Yakutsk region and laid the foundation of its entry to the system of relations with the Russian authorities.

Historical sources show us that, initially, the extensive region which included the territories at the junction of the Yenisei and the Lena River systems and beyond them, was a part of the Yenisei uyezd. Regular equipping of units of service class people to this region was started by Tobolsk, Mangazeya and Yenisei voevodas (military governors appointed to administer and defend uyezds) in 1632. Due to the inconsistency of their actions, tyranny and armed clashes between them, the local population was often forced to pay double and triple yasak, it caused hostile attitude towards service class people.

Historical materials mention that haphazard actions of pioneers which caused rejection on the part of the indigenous people, forced the Russian government in the 1640 to establish a special administrative center on Lena which also had to serve as a basis for further spread of the influence of the Russian state in the East. Therefore, the relevant departments of Moscow government in 1633-1638 studied the question about bringing discipline to the management of the outlying areas. They collected information from Tobolsk, Yenisei and Mangazeya voevodas, and questioned ordinary service class people who had visited the Lena region. As the result, in 1638 it was decided to establish an independent Yakutsk uyezd, which was directly subordinated to 
Siberian ministry in Moscow (Safronov, 1987). Yakutsk fort was chosen as its center and located in Yakutia region at the intersection of water and land roads linking its different parts (Figure 2). In other words, there were significant changes in territorial organizational structure of the region already at the initial stage if development of Siberian territory.

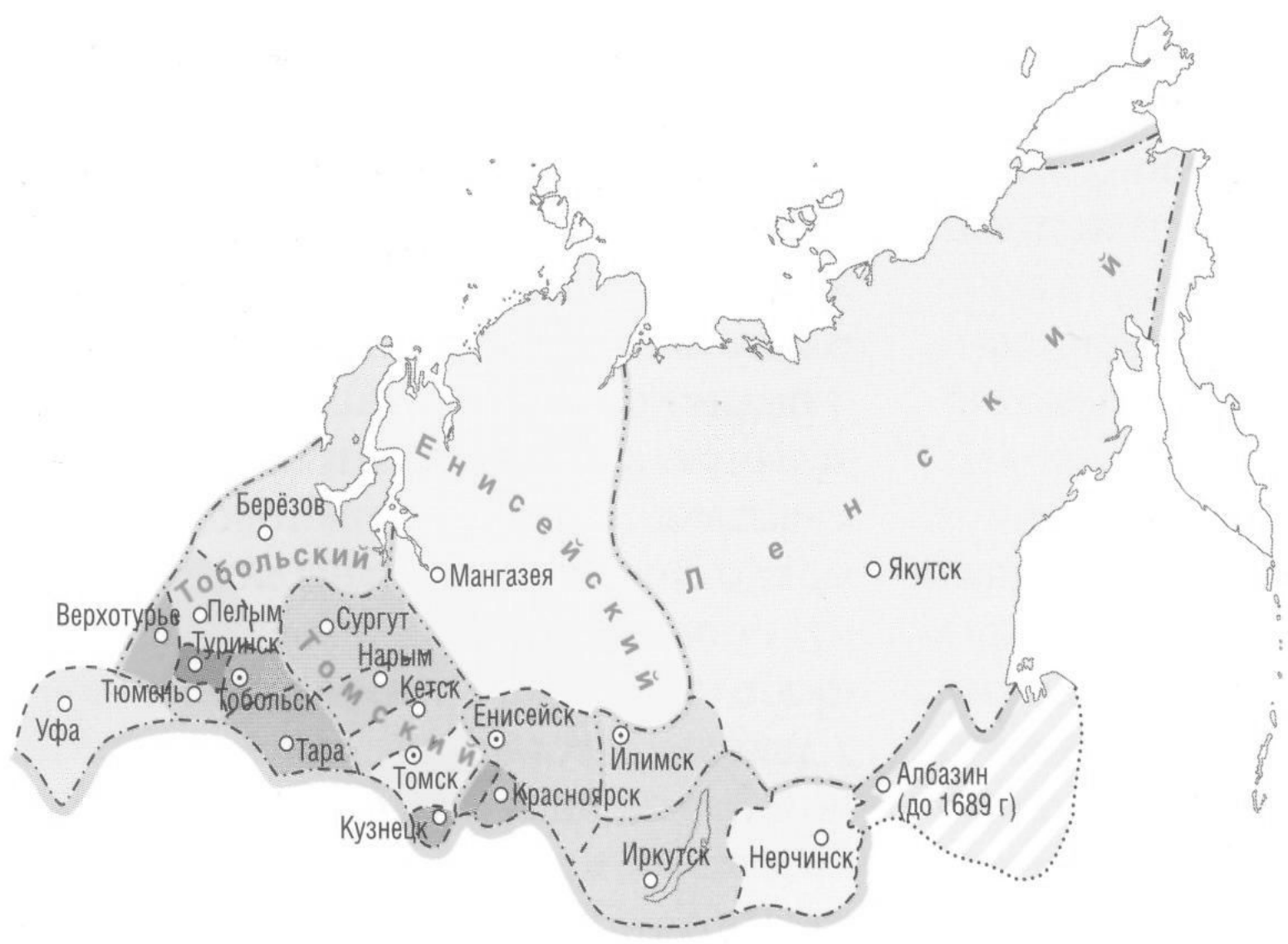

Captions:

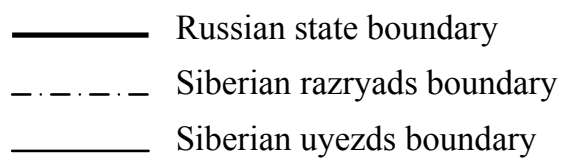

Figure 1. Administrative structure of Siberia in the XVIIth century. (Yakutia. Historical and cultural atlas. Moscow. Feoria, 2007, p. 213) 


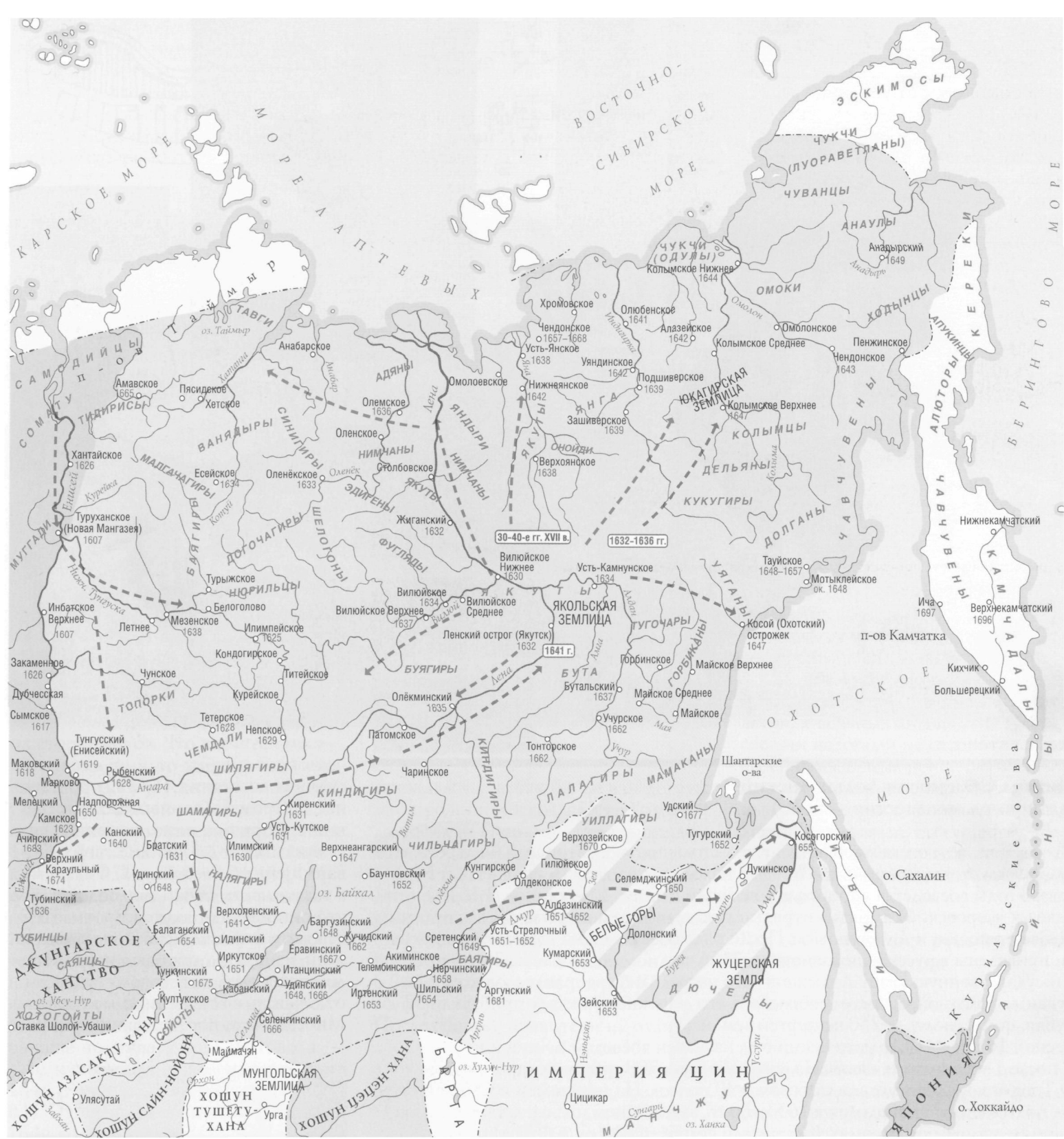

Figure 2. Yakutsk uyezd in the first half of the XVII ${ }^{\text {th }}$ century. (Yakutia. Historical and cultural atlas. Moscow.

Feoria, 2007, p. 205)

The report made by Mangazeya voevoda A. F. Palitsyn is one of historical sources dealing with the organization of Yakutsk uyezd. It includes profiles of the territory of the Yakutsk region and the inhabiting peoples, and had drawings and catalogue of lands attached hereto. According to V. N. Ivanov, a well-known historian in the region, the main basis for the establishment of Yakutsk uyezd were mainly fur resources which replaced currency in those days, as well as the fact that the management of the region from other Siberian settlements was almost impossible. Unknown lands to the east of Yakutsk uyezd which were capable to provide large revenues to the state was also taken into account (Ivanov, 1964).

By the time of establishment of Yakutsk uyezd the whole region near the Lena River and the whole country to the East of it up to the Okhotsk Sea comprised a single province and subordinated forts and yasak winter huts scattered across North-Eastern Siberia. Yakut voevodas appointed ministry people in all the secondary points and controlled their activities. That's why Yakutsk uyezd equated to the razryad and was often called Lena razryad in documents (Yakutia, 1953). 
The boundaries of the uyezd were approximately set in the directive of Siberian ministry given to the first voevodas P. P. Golovin and M. B. Glebov in 1638 (Safronov, 1978). This uncertainty was the result of ignorance of specific data on the region. However, the issue was cleared up with the arrival of voevodas. The uyezd included the whole basin of one of the greatest rivers in the world as well as the entire system of Ilim River that flows into the Upper Tunguska River. Then the boundary ran along the watershed of the Yenisei and Lena rivers, including headwater of the Viluy River. Boundaries in the North, East and South were gradually established. Due to the further extension of the Russian power by the end of the 1640s they corresponded to the natural boundaries: the coast of the Arctic and Pacific Oceans, and Stanovoy Range. At the end of XVII - beginning of XVIIIth century the whole Kamchatka Peninsula joined the uyezd. As a result, the uyezd boundaries have gone far beyond Yakut region itself, uniting a vast territory of the North-East Asia. As there searches note, there was not a single uyezd in the vast Moscow tsar dom that would remotely approximate to the territory of Yakutsk uyezd. Further changes of the boundaries had little impact on this situation (Safronov, 1978).

In 1648 the upper reaches of the Lena River, the Lena portage and basin of Ilim were separated as the independent Ilim uyezd. The necessity of it had already been shown in 1642 by voevodas P.P. Golovin and M.B. Glebov. As noted by F.G. Safronov, are known historian of the region, the Siberian ministry did not hurry with this decision and only after Yakut service class people raised this issue again in 1648, focusing on the difficulties encountered when sending yasak furs to Moscow, the issue was resolved positively. Only after receiving the reports of these people in the same year, the Moscow government sent a first voevoda to Ilimsky fort (Safronov, 1978).

We can learn from the works of F. G. Safronov that since that time, the South-Eastern boundary of Yakutsk uyezd passed on Chechuysk portage (downstream Kirensk fort on the Lena River). However, in some time the successors of P. P. Golovin and M. B. Glebov, due to systematic lack of grain supplies from Yenisei and Ilimuyezds, applied for getting grain-producing volosts of upper reaches of the Lena River to Yakutsk uyezd back. We also find in the works of F. G. Safronov that in 1652-1653 voevoda M. S. Lodyzhensky and clerk F. Tonkov requested to transfer the area near the Kirenga River to Yakutsk uyezd, citing the fact that it would be easier for the authorities to do business in these small settlements than for Ilim voevodas, because of remoteness of that areas. But their requests was not taken into account for a long time. And only the urgent need for bread to feed the service class people made it possible to transfer seven upper-Lena volosts - Birulskaya, Tuttursjaya, Ilginskaya, Ordenskaya, Ust-Kutskaya, Krivolukskaya and Verkhnekirenskaya - to Yakut voevodas. However, in 1698 they were given back to Ilim uyezd. Then, a short time later, there was a new change. Apart of Ust-Kut, Krivolukskaya, Verkhnekirenskaya and Nizhnekirenskaya volosts were transferred back to Yakutsk uyezd in 1699 , and thus, its South-Western boundary then passed along the Kuta River in the upper reaches of the Lena River. Things were changed only in February 27, 1704 when these volosts were transferred back to Ilimsk (Safronov, 1978).

The territory of Yakutsk uyezd then underwent several changes both in its composition and administrative structure.

In the XVIIth century before the arrival of the first Cossack detachments and service class people, the Yakuts the largest group of the peoples of that region, according to the study conducted by D.M. Pavlinov, N.A. Vitashevsky and L.G. Levental, lived a triable life and were divided into clans headed by clan elders or kniaztsy (toyons). Despite the fact that the territories populated by them, were not delineated between the clans, each group had determined and strictly demarcated places for economic activities and living. It was not hard to notice how fragile and unstable in terms of time these boundaries were. With the arrival of Russians, all the lands allotted to each clan, were approved with statements which were stored in the Voevodas' Office (Pavlinov, Vitashevsky, \& Leventhal, 1929).

The territory was simultaneously divided into volosts taking into account easier collection of yasak by the service class people. The volosts began to appear in 1632, and by the early 1640 s they became 36 . They were formed gradually with identifying non-yasak people and their habitats. It should be noted, that these volosts were initially formed only in the center of Yakutia where most of Yakuts lived. They corresponded to the places of residence of clans and tribes. According to O.V. Ionova, division of the inhabited territory into "volosts" in this period allows thinking that it was only fixing social structure of the Yakut according to local kniaztsy (Ionov, 1957). The first units of service class people had neither time nor conditions to implement any administrative division. At first, they had to deal with knyaztsy who occupied a certain area, which became known as a volost or ulus.

Yakutia was named "Yakolskaya zemlitsa (land)" in the "Book of yasak collection of Enisei fort by Ataman Ivan 
Galkin" dated 1631-1632. In this book the territories of groups of Yakuts who paid yasak are named uluses. B.O. Dolgikh, a prominent specialist in the ethnography of Siberian peoples, believes that this name includes Kangalassky, Betunsky, Butulinsky, Meginsky and Namskyuluses (Dolgikh, 1960).

Beginning from the book by P. Beketov (1632-1633) and his service record, the Yakuts of the central part of the region are grouped in 16 volosts (Table 1) (Safronov, 1987).

Table 1. List of volosts of Yakutsk uyezd in yasak books and service records of service class people

\begin{tabular}{|c|c|c|c|}
\hline Year & Name of document & $\begin{array}{c}\text { Amount of } \\
\text { allocated } \\
\text { administrative } \\
\text { areas }\end{array}$ & Allocated administrative areas \\
\hline 1631 & $\begin{array}{l}\text { Book of yasak } \\
\text { collection by Ataman } \\
\text { Ivan Galkin }\end{array}$ & 5 & $\begin{array}{l}\text { Uluses: KangalasskH, Betunsky, Butulinsky, Meginsky, } \\
\text { Namsky }\end{array}$ \\
\hline 1632 & $\begin{array}{l}\text { Yasak book by Piotr } \\
\text { Beketov* }\end{array}$ & 16 & $\begin{array}{l}\text { Volosts: Mastyatskaya, Maganskaya, Butunskaya, Namskaya, } \\
\text { Gasilinskaya, Khagalaskaya, Tagunskaya, Niuriupteyskaya, } \\
\text { Mangunskaya, Baksinskaya, Batulinskaya, Modunskaya, } \\
\text { Katulinskaya, Dubsunskaya, Gubsunskaya, Chiuriukteyskaya* }\end{array}$ \\
\hline 1633 & $\begin{array}{l}\text { Yenisei fort service } \\
\text { records by sotnik } \\
\text { Piotr Beketov } * *\end{array}$ & 16 & 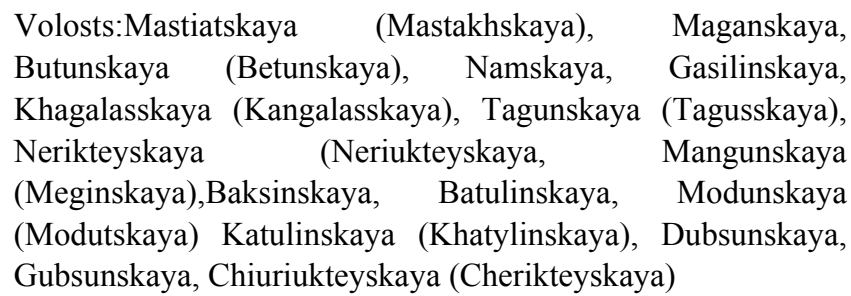 \\
\hline 1639 & $\begin{array}{l}\text { Yasak book by } \\
\text { Yenisei boyar son } \\
\text { Parfen Khodyrev* }\end{array}$ & 32 & 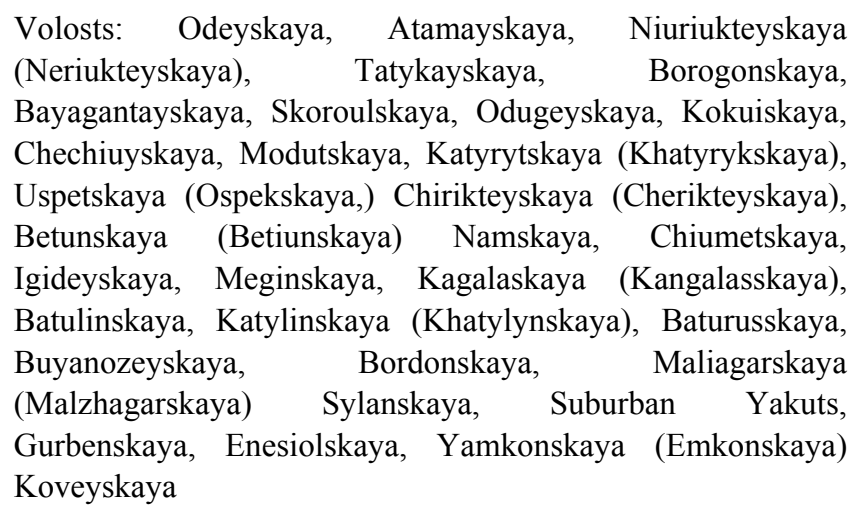 \\
\hline 1640 & $\begin{array}{l}\text { List of volost names } \\
\text { published by S.A. } \\
\text { Tokarev* }\end{array}$ & 36 & $\begin{array}{l}\text { Volosts: Kangalasskaya, Baturusskaya, Kytylinskaya, } \\
\text { Niuriukteyskaya (Neriukteyskaya), Meginskaya, Betunskaya } \\
\text { (Betiunskaya), Namskaya, Borogonskaya, Chumetskaya, } \\
\text { Atamayskaya, Sylanskaya, Dukbchinskaya (Diupsinskaya), } \\
\text { Skoroulskaya, Emkonskaya, Boyanazeyskaya, Katyrytskaya } \\
\text { (Khatyrykskaya), Nakarskaya (Nakharskaya), Suburban, } \\
\text { Modutskaya, Uspetskaya (Ospekskaya), Chirikteyskaya } \\
\text { (Cherikteyskaya), Batulinskaya, Malyagarskaya } \\
\text { (Malzhagarskaya), Odeyskaya, Bordonskaya, Gurmenskaya, } \\
\text { Yarkanskaya (Zharhanskaya), Magasskaya, Odugeyskaya, } \\
\text { Bayagantayskaya, Igideyskaya, Odayskaya (Odeyskaya) } \\
\text { Chechuyskaya, Olesskaya, Orgutskaya, Tagusskaya }\end{array}$ \\
\hline
\end{tabular}

\footnotetext{
*TokarevS. A. Social structure of Yakuts in the XVII-XVIII centuries. Yakutsk, 1945, p. 38.
}

** Safronov F. G. Yakuts. Village-community management in the XVIIth - at the beginning of the XXth century. Yakutsk. Publishing house, 1987, p. 7.

Some names of volosts are mentioned only in this list while the others are repeated in later lists. 
Yasak book of Yenisei fort by Ivan Galkin (1638) mentions 32 volosts. Similar book by Yenisei boyar son Parfen Khodyrev dated 1639-1640 mentions 3 volosts which are not found in further documents: Tatyksayskaya (as B. O. Dolgikh thinks, it is a distorted name of Kachikatskaya volost), Kokuyskaya (name of Ust-Viluyskaya volost) and Enesilskaya (in later lists of volosts it is probably named as Yarkanskaya).He also cites the names of two more volosts - Dubchinskaya and Odeyskaya and believes that by 1639-1640 there were not 32, but 34 volosts throughout the central part of the Yakutsk region (Dolgikh, 1960).

According to historians, the final list of volosts was established in 1640, it proceeds from one list of yasak books to the others until the second decade of the XVIIIth century without any changes, keeping the sequence of names.

It is known that in the XVIIth century the territory of the central part of the region was divided into five suburban uluses for administrative purposes: Kangalassky, Baturussky, Namsky, Borogonsky and Meginsky between which naslegs (agricultural communities) were distributed. The naslegs corresponded to volosts in the European Russia. Each ulus was headed by an ulus chief, and naslegs were headed by "naslezhnye" kniaztsy, who managed clans, wich were part of a nasleg, with help of clan elders. Locations of all these volosts are easily defined by names of uluses preserved until the first decades of Soviet period (Table 2).

Table 2. Number of yasak payers (adult males), persons*

\begin{tabular}{|c|c|c|c|c|c|}
\hline No. & Name of volost & $1648-1649$ & $1655-1656$ & $1663-1664$ & $1680-1681$ \\
\hline 1 & Kangalasskaya & 150 & 328 & 585 & 581 \\
\hline 2 & Buturusskaya and Katylinskaya & 141 & 289 & 731 & 835 \\
\hline 3 & Niuriupteyskaya & 59 & 141 & 277 & 343 \\
\hline 4 & Meginskaya & 213 & 426 & 871 & 876 \\
\hline 5 & Betunskaya & 95 & 208 & 423 & 536 \\
\hline 6 & Namskaya & 99 & 267 & 515 & 538 \\
\hline 7 & Borogonskaya & 111 & 265 & 555 & 651 \\
\hline 8 & Chumetskaya & 2 & 13 & 15 & 14 \\
\hline 9 & Atamayskaya & - & 32 & 76 & 74 \\
\hline 10 & Sylanskaya & 41 & 29 & 117 & 150 \\
\hline 11 & Dubchinskaya & 23 & 42 & 105 & 138 \\
\hline 12 & Skoroulskaya & 27 & 55 & 107 & 121 \\
\hline 13 & Emkonskaya & 16 & 42 & 82 & 100 \\
\hline 14 & Boyanazeyskaya & 32 & 52 & 90 & 135 \\
\hline 15 & Katyrytskaya & 7 & 24 & 46 & 49 \\
\hline 16 & Nakarskaya & 4 & 48 & 100 & 132 \\
\hline 17 & Podgorodnaya & 13 & 32 & 38 & 34 \\
\hline 18 & Modutskaya & 30 & 48 & 107 & 118 \\
\hline 19 & Uspetksaya & 47 & 99 & 209 & 231 \\
\hline 20 & Chirikteyskaya & 39 & 90 & 199 & 208 \\
\hline 21 & Batulinskaya & 41 & 120 & 303 & 368 \\
\hline 22 & Maliagarskaya & 65 & 130 & 198 & 205 \\
\hline 23 & Odeyskaya & 47 & 100 & 156 & 150 \\
\hline 24 & Bordonskaya & 30 & 67 & 108 & 121 \\
\hline 25 & Gurmenskaya & 17 & 13 & 20 & 17 \\
\hline 26 & Yarkanskaya & 5 & 6 & 41 & 48 \\
\hline 27 & Magasskaya & 9 & 19 & 50 & 59 \\
\hline 28 & Odugeyskaya & 15 & 38 & 102 & 128 \\
\hline 29 & Bayagantayskaya & 32 & 54 & 154 & 249 \\
\hline 30 & Igideyskaya & 29 & 64 & 141 & 149 \\
\hline 31 & Odeyskaya & 11 & 21 & 44 & 33 \\
\hline 32 & Chechuyskaya & 20 & 39 & 122 & 128 \\
\hline \multirow[t]{2}{*}{33} & $\begin{array}{l}\text { Volosts on the Toksoma lake: Olesskaya, } \\
\text { Orgutskaya, Tagusskaya including Yakuts of }\end{array}$ & & & & \\
\hline & Sobonitksya volost & 57 & 36 & 42 & 65 \\
\hline
\end{tabular}

*Tokarev S.A. Social structure of Yakuts in the XVII-XVIII centuries. Yakutsk, 1945, p. 38. 
Historians of the region created an approximate plan of geographical localization of individual volosts. Thus, Namskaya volost in the XVIIth century was located on the left bank of the Lena River, downstream of Yakutsk; Kangalasskaya volost located on the same bank of the Lena River, upstream of Namksaya volost; Meginskaya volost occupied the territory from the right bank in front of Yakutsk (including the islands on the Lena River) up to the headwaters of the Solo River. Betunskaya volost was located near the estuary of the Aldan River on its left side around the Taragan Lake where Betiunsky and Kobekonsky naslegs of Namsky ulus were situated. Baturusskaya, Batulinskaya and Igideyskaya volosts were located on rivers Amga and Tata; Borogonskaya, Chirikteyskaya volosts were on the Tanda River; Dubsinskaya volost was located on the Maldan River, apparently, near the place where the rivers Amga and Tata falls into it, and Ospetskaya volost was on the way between them and Yakutsk fort; Yemkonskya volost was located on the Boroma River; Boyanazeyskaya and Atamayskaya volosts were on the Sita River. However the volosts did not represent certain territorial divisions. One could belong to one volost but live in another one. It turns out that the territorial connection was not the only factor that united people of one volost together; there were other relations that haven't been broken when moving to another territory. In other words, according to S.A. Tokarev, a well-known historian of the region, the volosts represented tribal groups (Tokarev, 1945).

Data on the number of yasak population of individual volosts, according to S.A. Tokarev, indicate that their population was not the same. The largest volosts- Meginskaya, Baturusskaya, Kangalasskaya, Borogonskaya, Namskaya and Betunskaya - comprised from 500 to 900 adult males; hence, their overall composition of population including women and children must be $2-5$ thousand in each. Along with large volosts, there were medium volosts with 100-200 males, i.e. 400-1000 persons, and, finally, there were very small volosts such as Chumetskaya, Gurmenskaya, male composition of which did not exceed 20 persons, that is, the entire population was less than 100 persons in each. These small volosts could hardly be named tribes, due to their size, that's why the word "clan" was more suitable for them (Tokarev, 1945).

There were no volosts throughout the rest of the vast territory of the Yakutsk region. According to F. G. Safronov, its population, with inclusion in Russia, was attributed to the respective fortified points - yasak winter huts, outposts and forts, where Cossacks headed by ministry people were sent (Safronov, 1961). It is sometimes very difficult to establish years of foundation of such points, and sometimes even impossible. Almost all the researchers agree that it is difficult to establish their original location as it was often changed. Their names changed, too. There were also winter huts that existed for a short time. Service class people usually built fortified points in the center of habitation where there were places for fishing and hunting, changes of which sometimes resulted in transfer of winter huts and outposts and simultaneously, in change of their names.

Thus, by the end of the XVIIth century there were 36 volosts, 29 of which were permanent and 11 - temporary peripheral forts, outposts and yasak winter huts, for a total of 76 units of territorial structure of the region.

Due to its vast territory, equal to almost half of all Siberia, Yakutsk uyezd had a special status among other uyezds of Tsarist Russia, which were more than 140 in the end of the XVIIth century. In addition, the uyezd was in the border area and, therefore, equated to a razryad (it has already been mentioned earlier). In the XVIIth century in some Russian border areas which were threatened by external enemies, large military administrative regions (razryads) were built. They consisted of several uyezds, such as Smolensk, Belgorod and Sevsk razryads. These administrative units were created in Siberia, too. Yakutsk uyezd was not officially a razryad, as Yakutsk subordinated not cities with voevodas but out posts and yasak winter huts governed by ministry people. However, in some documents (especially, yasak, customs, estimate books, etc), according to F. G. Safronov, the expressions as the following: "Yakutsk city of Lena razryad..." were frequent. Probably, a great quantity of forts, out post sand winter huts located through out the uyezd, was taken into account and the ministry people sent there by voevodas equated to razryad voevodas (Safronov, 1978).

Yakutsk uyezd, as well as elsewhere, was headed by voevodas. There were about 20 voevodas in Yakutsk from 1641 to 1701.Most of them held the position for three or four years, some - for two years, but there were also those who were in office for six or seven years. In fact, there was no determined age of service for Siberian voevodas until the end of the XVIIth century. But still, it was considered that a voevoda had to serve for "four, five or six years depending on the person". One who "taught great sovereigns to do business and collect full revenues" had to stay in this position longer. According to F. G. Safronov, this order was kept until 1695 when the Edict of His Imperial Majesty on the service of Siberian voevodas was issued (Safronov, 1978).

Functions of voevodas were determined in instructions given to each newly appointed person by Siberian ministry. It was defense against external and internal enemies, collection of yasak "with profit", promoting trading and crafts of Russian people and their control, development of local ploughed fields to supply service 
class people with bread, the fight against smoking and gambling. Thus, the voevodas had in their hands military, civil, judicial and police power. They were also financial managers.

We know from historical data that in the XVIIth century there were four Russian peasant volosts in Yakutsk region: Vitimskaya-Peleduyskaya, Olyekminskaya, Kangalasskaya and Amginskaya. Only the first consisted of two settlements, while the others had one village. Nevertheless, according to tradition they were called volosts, and only occasionally settlements (Vitim and Amgu), fort (Oliekminskaya), and zaimka (small settlement) (Kangalasskaya). Each volost was ruled by an estate manager appointed by the voevoda from service class people, excluding Kangalasskaya volost, where due to the small number of farmers, functions of this official were performed by the headman of peasants.

The administrative system of Siberia in the first half of the XVIIth century, was unchangeable until 1708, when guberniyas (provinces) were established. The general management of Siberia was entrusted to Siberian Ministry, which resided in Moscow, and administration was carried out by Tobolsk Cossacks.

\section{Conclusion}

Gradual arising and formation of settlement network of Yakutia in the XVIIth century according to its territorial and organizational structure are disclosed. There is a theoretical significance in historical and geographical researches of Yakutia, as the material is for the first time generalized from various publications about history of the Nort-East of Russia. Relevance of article is defined by growing interest in republic to history of the Yakutian formation as independent territorial autonomous unit within the Russian Federation.

The author adheres to historians' general opinion to the effect that on the territory of Yakutia weren't rural settlements as one understands them today, but there were compact residence territories of different tribes and clans of the Yakut people and certain territories of nomadic peoples, living on the territory of modern Yakutia, which afterwards were issued in the form of administrative-territorial entities, and much later in these territories were appeared the first rural settlements, bearing the names of residence clans, tribes or their self-name. It is noted that the first urban settlements appeared with arrival of the Russian service class people, which formed a compact place for residence in the form of stockaded towns and then became the cities.

Thus, territorial and organizational structure of Yakutsk region at a nearly stage, before the arrival of Russian service class people, represented location of tribal groupings and corresponded to the places of residence of clans and tribes. The territory of residence of population was divided into volosts only after the establishment of yasak tax. This division only fixed social structure of the Yakut according to oral information provided by Yakut kniaztsy. At first, service class people had to deal with the kniaztsy, who occupied certain areas, which were considered as the first geographical management units and the base of settlement network frame for further settlement of population. During the XVIIth century the region underwent such changes as development and settlement of its central part, and to some extent, its peripheral areas, delineation of its boundaries, with simultaneous establishment of internal administrative units (uluses, volosts), which were prototypes of the future centers of administrative regions.

\section{References}

Dolgikh, B. O. (1960). Clan and tribal peoples of Siberia in the composition of the XVII century. Moscow: Publishing House of the USSR Academy of Sciences.

Ionov, O. V. (1957). Yakutia joining the Russian state - History of the Yakut ASSR. T. 2. Moscow: Nauka.

Ivanov, V. N. (1964). Education of Yakut County. Yakut archive (collection of articles and documents). Yakutsk, Yak. book.

Nikolai A. T. (1987). The problems of the origin and ethnic history of the Turkic peoples of Siberia. Tomsk: Tomsk University.

Pavlinov, D. M., Vitashevsky, N. A., \& Leventhal, L. G. (1929). Materials on customary law and public life of Yakuts. Proceedings of the commission to study the Yakut Autonomous Soviet Socialist Republic, T. 4.

Safronov, F. G. (1961). Russian peasants in Yakutia (the XVII - beginning of XX century). Yakutsk: Publishing House.

Safronov, F. G. (1978). Russian in the north-east of Asia in the XVII - the middle of the XIX centuries. Moscow: Nauka.

Safronov, F. G. (1987). Yakuts. Worldly management in the XVII - beginning of XX century. Yakutsk, Yak. book.

Tokarev, S. A. (1945). Social system of Yakuts in the XVII-XVIII centuries. Yakutsk. 
Yakutia in the XVII century. (1953). Yakutia in the XVII century. Yakutsk.

\section{Copyrights}

Copyright for this article is retained by the author(s), with first publication rights granted to the journal.

This is an open-access article distributed under the terms and conditions of the Creative Commons Attribution license (http://creativecommons.org/licenses/by/3.0/). 